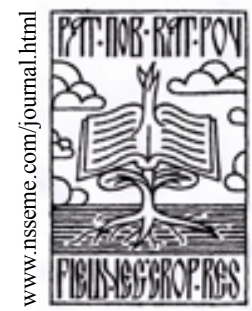

\title{
Correlation and Path Analysis for Yield and Yield Components in Common Bean Genotypes (Phaseolus vulgaris L.)
}

\author{
Mustafa Önder • Ali Kahraman • Ercan Ceyhan
}

\author{
received: 30 May 2013, accepted: 15 July 2013 \\ published online: 30 October 2013 \\ (c) 2013 IFVC \\ doi: $10.5937 /$ ratpov50-3958
}

\begin{abstract}
Summary: Determination of breeding criteria is quite important for plant breeders. The present study was carried out to determine yield and its components which are affecting seed yield and to study the relationships between yield components and other characteristics. A total of 42 common bean genotypes that are widely grown in Turkey were used as material. Direct and indirect effects of the yield components on seed yield were analyzed using path coefficient analysis. Seed yield (kg $\mathrm{ha}^{-1}$ ) was most affected by biologic yield $(84.56 \%)$, harvest index $(65.47 \%)$ as positive and negatively affected by number of main branches per plant $(28.45 \%)$ and flowering day $(13.27 \%)$ respectively. Correlation analysis showed that seed yield $\left(\mathrm{kg} \mathrm{ha}^{-1}\right)$ was effected by biologic yield $\left(0.8224^{* *}\right)$, harvest index $\left(0.2913^{* *}\right)$ as positive and negatively affected by flowering day $\left(-0.3256^{* *}\right)$, first pod height $\left(-0.2473^{* *}\right)$, plant height $\left(-0.2406^{* *}\right)$ and pod number per plant $\left(-0.2272^{*}\right)$ respectively. According to the path analysis, the biologic yield, harvest index, number of main branch per plant and days to flowering are important due to direct effect on the increase of seed yield on selection studies.
\end{abstract}

Key words: beans, path coefficient, seed yield, yield components

\section{Introduction}

Dry bean has superior adaptation ability. It has a wide range of genetic diversity in Turkey especially in Konya which has the most production quantity. A previous research showed that a total of 38 common dry bean genotypes were ranged as the values from 0.48 to 0.97 genetic similarity degrees which welded the ISSR method. Several researches related to the yield of dry bean $\left(\mathrm{kg} \mathrm{ha}^{-1}\right)$ in different regions of Turkey was summarized as following: 840-1320 in Ankara (Şehirali 1971), 2341 in Erzurum (Akçin 1974), 1150-2260 in Samsun (Özçelik \& Gülümser 1988), 1130-1150 in Van (Yılmaz \& Çiftçi 1994), 574-1196 in Çukurova (Anlarsal et al. 2000), 692.9-1550.7 in Konya (Kahraman \& Önder 2009).

Seed yield is one of the main purposes in breeding programs. It is recommended to develop the useful plant genotypes which are adaptive to the region. In this respect, breeders who need to

M. Önder • A. Kahraman* • E. Ceyhan

University of Selcuk, Faculty of Agriculture, Department of Field Crops, 42075, Konya, Turkey

e-mail:kahramanali@selcuk.edu.tr specify the basics of selection should determine the impact factors and the degree of relationships through yield components (Torun \& Köycü 1999). Understanding of the interactions between the plant characteristics which are effective in the region, component of yield and quality in plants is the main principle of the variety improving programs (Poehlman 1979). Yield is a quantitative characteristic which is under the effects of many factors by means of genetic structure. Some of the characters affect the yield as directly while the others effect indirectly (Önder \& Şentürk 1996). Therefore, path analysis is used as a supplement component of correlation coefficients. This calculation allows separation of components as their direct and indirect effects and it uses a standard partial regression coefficient (Ghoss \& Chatterjee 1988, Shabana et al. 1990). Path analysis method gives the exact idea about the effects of every single characteristic on yield or quality (Önder

\section{Acknowledgements}

We are thankful to Selcuk University, Coordinator of BAP (Project number: 06401030) for their financial support and Prof. Dr. Önder Turkmen and Expert Musa Seymen at the Selcuk University, Faculty of Agriculture, Department of Horticulture for their incontrovertible contributions. 
1995, Önder 1996, Önder \& Akçin 1996, İşler \& Çalışkan 1998, Önder \& Babaoğlu 2001).

This research was made to estimation of the correlations and path analysis among some important characteristics in dry bean genotypes to determine selection criteria for high yield. Using correlation alone is not enough to understand the importance of the direct and indirect influence from individual components on seed yield. Therefore, path analysis was made to figure out the section criteria which based on seed yield.

\section{Materials and Methods}

In this research, a total of 42 common bean genotypes (Table 2) that are widely grown in Turkey were used as material. All of the used common bean genotypeswere collecteddependingon thefollowing criteria: situation of preference, stability status over years, harvested in the last year, high market and cooking quality. The growth type of the used genotypes is dwarf. Field observations which were performed according to the randomized complete block design with three replications during the year of 2008 were as follows: days to flowering, number of main branches per plant, number of leafs per plant (during flowering time), plant height $(\mathrm{cm})$, number of pod per plant, number of seed per pod, first pod height $(\mathrm{cm})$, biologic yield $\left(\mathrm{kg} \mathrm{ha}^{-1}\right)$, yield $\left(\mathrm{kg} \mathrm{ha}^{-1}\right)$, harvest index (\%) and 1000 seed weight $(\mathrm{g})$. The means of investigated characteristics of the used genotypes were used in a different study which is entitled as "Determination of Yield and some Yield Components of Common Bean (Phaseolus vulgaris L.) Genotypes that Grown in Konya Province" as an oral presentation in Hatay/Turkey (Kahraman \& Önder 2009).

The relationships between the investigated characteristics and seed yield per plant, correlation coefficients, direct and indirect effects were performed using "TARIST" computerized statistical program.

\section{Results and Discussion}

Summary of the analysis of variance and the investigated values is shown in Table 1 . Most of the investigated characteristics showed statistically importance at the level of $1 \%$.

Analysis to determine the correlation coefficients (Table 2) revealed that seed yield was affected by biologic yield $\left(0.8224^{* *}\right)$, harvest index $\left(0.2913^{* *}\right)$ as positive and negatively affected by flowering day $\left(-0.3256^{* *}\right)$, first pod height $\left(-0.2473^{* *}\right)$, plant height $\left(-0.2406^{* *}\right)$ and pod per plant $\left(-0.2272^{*}\right)$ respectively (Table 3 ).

Path analysis showed that the most important characteristics were the biologic yield, harvest index, number of main branch per plant and days to flowering, due to their direct effect on seed yield of the investigated common bean genotypes (Table 4).

According to the results of the present study, seed yield was mostly affected by biologic yield (84.56\%), harvest index $(65.47 \%)$ as positive and negatively affected by main branch per plant (28.45\%) and flowering day (13.27\%) respectively.

A previous research reported that the yield affecting factors in dry bean were number of pod per plant, number of seed per pod, weight of seed

Table 1. Variance analysis and values of the investigated characteristics

\begin{tabular}{|c|c|c|c|c|c|c|c|}
\hline \multirow[b]{3}{*}{ Characteristics } & \multirow{3}{*}{$\begin{array}{l}\text { Variance } \\
\text { analysis } \\
\text { summary }\end{array}$} & \multicolumn{6}{|c|}{ Genotype } \\
\hline & & \multicolumn{3}{|c|}{ Minimum } & \multicolumn{3}{|c|}{ Maximum } \\
\hline & & No & Name & Value & No & Name & Value \\
\hline Seed yield $\left(\mathrm{kg} \mathrm{da}^{-1}\right)$ & $\mathrm{XX}$ & 22 & Şeker & 69.29 & 12 & Amerikan Çalısı & 155.07 \\
\hline Days to flowering & ns & 29 & Üveynk & 40.67 & 34 & Ayşe Kadın & 58.00 \\
\hline Number of leaf per plant & $\mathrm{XX}$ & 44 & Horoz & 19 & 15 & Dermason & 42.50 \\
\hline Number of pod per plant & $\mathrm{XX}$ & 17 & Weihing & 10.05 & 6 & Horoz & 42.84 \\
\hline Number of seed per pod & $\mathrm{XX}$ & 19 & Akman 98 & 3.42 & 15 & Dermason & 7.67 \\
\hline Number of main branch per plant & ns & 15 & Dermason & 6.67 & 16 & Horoz & 10.33 \\
\hline Plant height $(\mathrm{cm})$ & $\mathrm{XX}$ & 20 & Amerikan & 31.23 & 22 & Şeker & 112.23 \\
\hline First pod height $(\mathrm{cm})$ & $\mathrm{XX}$ & 9 & Kanada & 4.60 & 19 & Akman 98 & 20.25 \\
\hline Harvest index (\%) & $\mathrm{XX}$ & 38 & Dermason & 33 & 8 & Bombay & 58 \\
\hline 1000 seed weight $(\mathrm{g})$ & $\mathrm{XX}$ & 2 & Sarıkız & 239.78 & 31 & Kırgız Yuvarlak & 416.15 \\
\hline
\end{tabular}

$\mathrm{XX}: \mathrm{p}<1 \%$, ns: not significant 
Table 2. Collection number (no), place (source) of collection and local names of the investigated dry bean genotypes ( ${ }^{*}$ : Certified lines)

\begin{tabular}{|c|c|c|}
\hline No & Place & Local name \\
\hline 1 & Başarakavak Town 1 & Horoz \\
\hline 2 & Başarakavak Town 2 & Sarıkız \\
\hline 3 & Başarakavak Town 3 & Kanada \\
\hline 4 & Çumra 1 & Şeker (Bıyıklı) \\
\hline 5 & Çumra 2 & Kırgız Çalısı \\
\hline 6 & Çumra 3 & Horoz \\
\hline 7 & Çumra 4 & Beyşehir Çalısı \\
\hline 8 & Çumra 5 & Bombay (Bomba) \\
\hline 9 & Çumra 6 & Kanada \\
\hline 10 & Altınekin 1 & Amerikan Kollu \\
\hline 11 & Altınekin 2 & Sarnıç \\
\hline 12 & Altınekin 3 (Mantar Village) & Amerikan Çalısı \\
\hline 14 & Konya (Center) & Gina \\
\hline 15 & Ereğli 1 (Center) & Dermason \\
\hline 16 & Ereğli 2 (Center) & Horoz \\
\hline 17 & Kadınhanı 1 & Weihing \\
\hline 18 & Kadınhanı 2 & Kanada \\
\hline 19 & Kadınhanı 3 & Akman $98^{*}$ \\
\hline 20 & Derbent 1 & Amerikan (Beretta) \\
\hline 22 & Derbent 5 & Şeker \\
\hline 23 & Beyşehir 1 (Göçü Village) & Horoz \\
\hline 24 & Seydişehir 1 & Sıra (originated from Çumra) \\
\hline 25 & Ilgın 1 (Beykonak Village) & Beyaz Horoz \\
\hline 27 & Sarayönü 1 & Kanada \\
\hline 28 & Sarayönü 2 (Bayramlı Village) & Amerikan Çalısı \\
\hline 29 & Yunak 2 & Üveynk (Veynk) \\
\hline 30 & Yunak 4 & Kanada \\
\hline 31 & Çumra 7 & Kırgız Yuvarlak (Kollu Barbunya) \\
\hline 32 & Derbent 2 & Yuvarlak Barbunya \\
\hline 33 & Akşehir 4 & Dermason \\
\hline 34 & Akşehir 5 (Sorkun Village) & Ayşe Kadın \\
\hline 35 & Akşehir 6 & Horoz (Oturak) \\
\hline 36 & Akşehir 7 & Dermason (Oturak) \\
\hline 37 & Kazım Karabekir 1 & Kanada (Kara Yaprak) \\
\hline 38 & Kazım Karabekir 2 & Dermason (Kırgız) \\
\hline 39 & Eskişehir- Anadolu Agr. Res. Ins. & Akman $98^{*}$ \\
\hline 40 & Eskişehir- Anadolu Agr. Res. Ins. & Eskişehir-855* \\
\hline 41 & Erzurum- Atatürk University & Elkoca-2005* \\
\hline 42 & Erzurum- Atatürk University & Kantar-2005* \\
\hline 43 & Çumra 8 & Amerikan Çalısı \\
\hline 44 & Derbent 3 & Horoz \\
\hline 45 & Akșehir 2 & Aysekadın \\
\hline
\end{tabular}



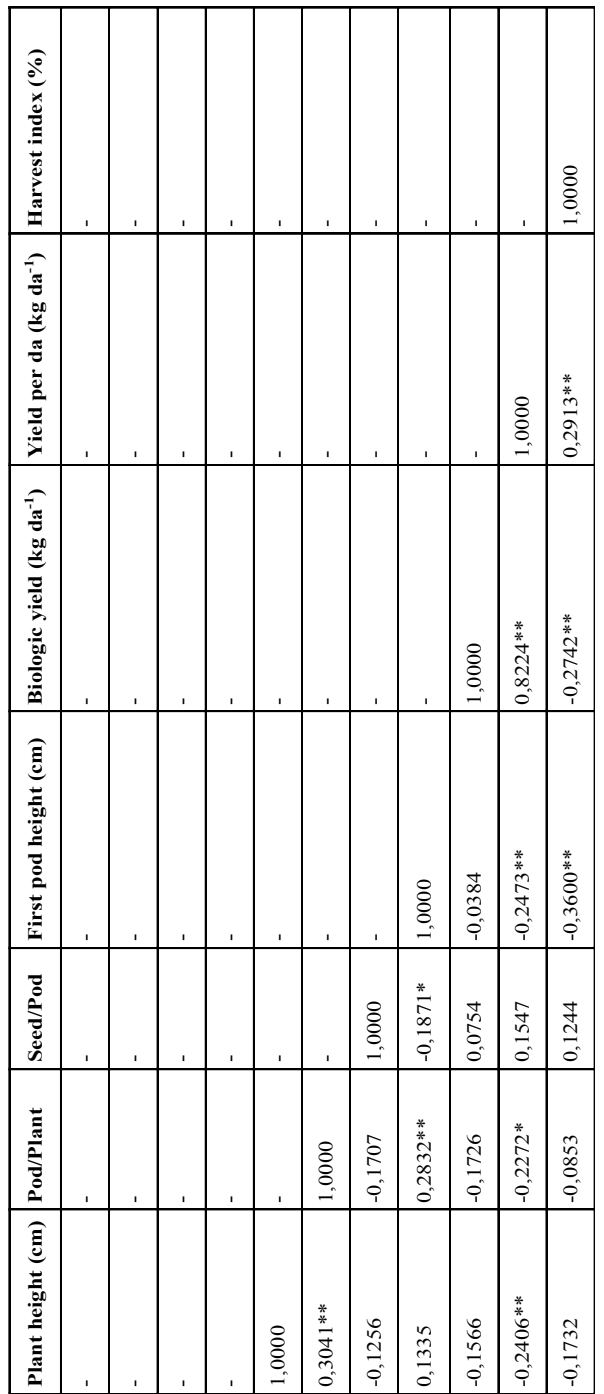

(.)

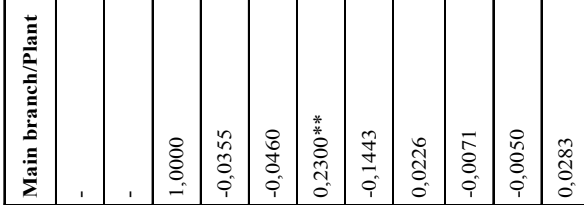

룡

1)
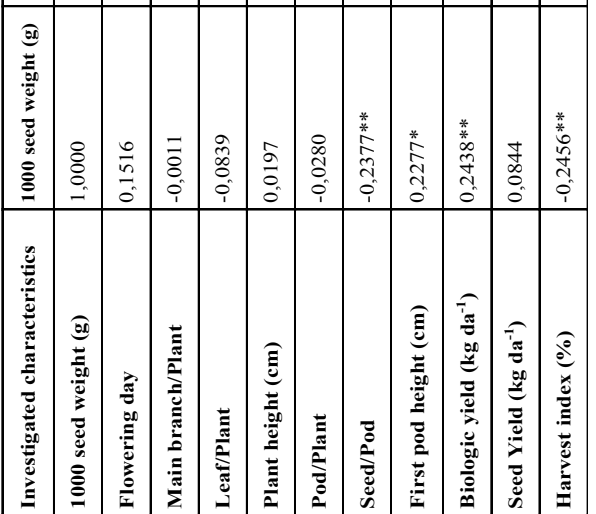

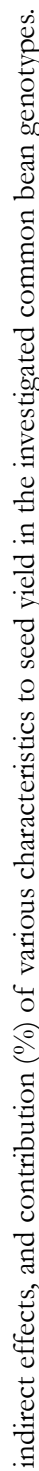

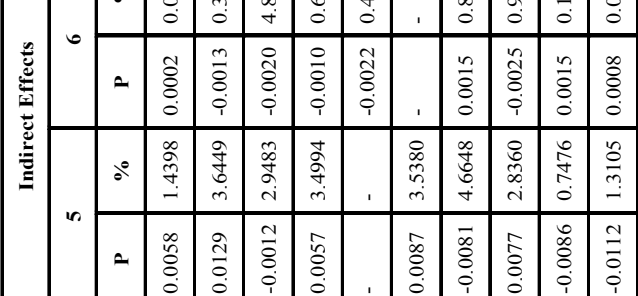

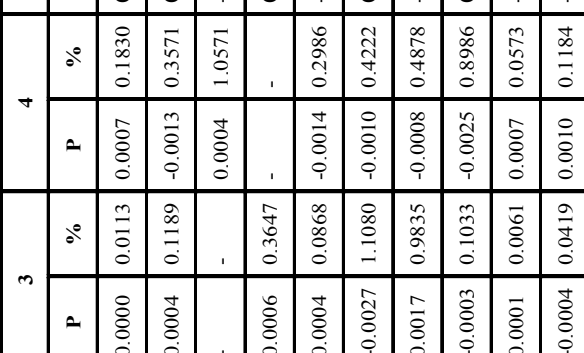

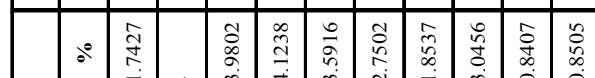

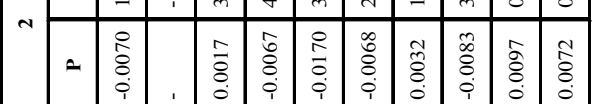

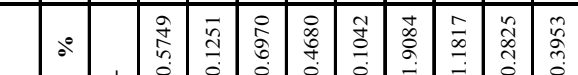

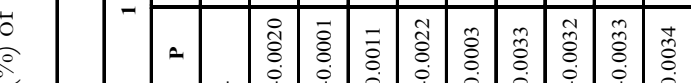

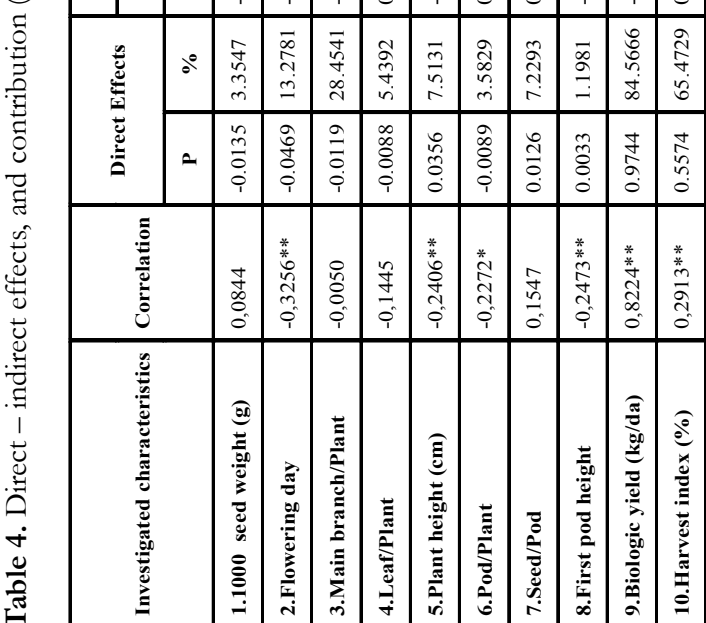


and number of plant in unit area. In this research, the results of path analyze were differed depending on varieties (Westermann \& Crothers 1977). Similarly, the most effective factors in common bean were determined as plant height, number of pod, number of seed per pod and 1000 seed weight (Önder \& Özkaynak 1994). Another research revealed that the bean characteristics such as number of seed per pod, number of leaf per plant, plant height and 1000 seed weight had direct effects on the yield (Yorgancilar et al. 2003).

Seed yield in bean showed positive and high level of relation with number of pod per plant, biologic yield, 1000 seed weight, plant height, harvest index, seed size index and flowering period (Bozoğlu \& Gülümser 1999).

Research in some common bean genotypes presented that seed yield had an important and positive relationship with plant height, and it had positive and high level of relationships with number of pod, number of seed per plant, length of pod, stem yield and height of first pod (Pekşen $\&$ Gülümser 2005). Path analysis revealed that the main contributors of seed yield were number of seed $(0.8605)$, average seed weight $(0.4314)$ and number of pod per plant $(0.3408)$ respectively due to their high, direct and positive effects. This valued research proved that the mentioned characteristics could be used as selection criteria to achieve high seed yield in breeding trials of common bean genotypes.

\section{Conclusions}

Data of the present research showed that the biologic yield and harvest index had positive effects on seed yield, while number of main branch per plant and days to flowering had negative effects on seed yield. Evaluation of the investigated common bean genotypes in terms of seed yield was also made by path analysis. This method put forth that the biologic yield, harvest index, number of main branch per plant and days to flowering had positive effects on seed yield.

Results of this study recommend that the mentioned characteristics could be used in common bean selection programs which are based on seed yield.

\section{References}

Akçin, A. (1974). Erzurum Sartlarında Yetiştirilen Kuru Fasulye Çeşitlerinde Gübreleme, Ekim Zamanı ve Sıra Aralığının Tane Verimine Etkisi İle Bu Çeşitlerin Bazı Fenolojik. In Morfolojik ve Teknolojik Karekterleri Üzerinde Bir Araştırma. Atatürk Ün. Yayınları.

Anlarsal, A.E., Yücel, C., \& ve Özveren, D. (2000). Çukurova Koşullarında Bazı Fasulye (Phaseolus vulgaris L.) Çeşitlerinde Tane Verimi ve Verimle İlgili Özellikler ile Bu Özellikler Arası İlişkilerin Saptanması. Turk J Agric For., 24, 19-29.

Bozoğlu, H., \& Gülümser, A. (1999). Kuru fasulyede (Phaseolus vulgaris L.) bazı tarımsal özelliklerin korelasyonları ve kalıtım derecelerinin belirlenmesi. In Türkiye 3. Tarla Bitkileri Kongresi (15-18 Kasim 1999), Cilt III. (pp. 360-365). Adana: ÇayırMera Yembitkileri ve Yemeklik Baklagiller.

Ghosh, R.K., \& Chatterjee, B.N. (1988). Path Analysis of Important Growth Functions of Indian Mustard (Brassica juncea L. Czern and Coss). Journal of Agronomy and Crop Science, 160(2), 116-121. doi:10.1111/j.1439-037X.1988. tb00305.x

İşler, N., \& Çalışkan, M.E. (1998). Gap bölgesi ekolojik koşullarında soyada (Glycine max (L.) Merr.) verim ve verime etkili bazı özelliklerin korelasyonu ve path analizi. Tr. J. of Agriculture and Forestry, 22, 1-5.

Kahraman, A., \& Önder, M. (2009). Determination of yield and some yield components of common bean (Phaseolus vulgaris L.) genotypes that grown in Konya Province. In Türkiye VIII. Tarla Bitkileri Kongresi, Cilt 1, s. 309-313 (Oral Presentation). 19-22 Ekim, Hatay, 2009.. (pp. 309-313).

Önder, M., \& Özkaynak, İ. (1994). Bakteri aşılaması ve azot uygulamasının bodur kuru fasulye çeşitlerinin tane verimi ve bazı özellikleri üzerine etkileri. Tr. J. of Agricultural and Forestry, 18, 463-471.

Önder, M. (1995). Kışlık kolzada dane ve yağ verimi ile bazı verim komponentlerinin korelasyonu ve path analizi. S. Ü.Ziraat Fakültesi Dergisi, 8(10), 39-49.

Önder, M. (1996). Soya dane, yağ ve protein verimi ile bazı verim unsurları arasındaki ilişkiler. S. Ü. Ziraat Fakültesi Dergisi, 10(12), 7-16.

Önder, M., \& Akçin, A. (1996). M3 generasyonundaki mutant fasulye hatlarında verim ve bazı verim öğelerinin korelasyonu ve path analizi. S. Ü. Ziraat Fakültesi Dergisi, 9(11), 83-90.

Önder, M., \& Şentürk, D. (1996). Ekim zamanlarının bodur kuru fasulye çeşitlerinde dane ve protein verimi ile verim unsurlarına etkisi. S. Ü. Ziraat Fakültesi Dergisi, 10(13), 7-18.

Önder, M., \& Babaoğlu, M. (2001). Interactions amongst grain variables in various dwarf dry bean (Phaseolus vulgaris 1.) cultivars. Journal of Agronomy and Crop Science, 187, 19-23.

Özçelik, H., \& Gülümser, A. (1988). Bazı Bodur Fasulye Çesitlerinde verim ve verim Ögeleri Üzerinde Bir Arastırma. 19 Mayıs. Uni. Zir. Fak. Der., 3(1), 99-108.

Pekşen, E., \& Gülümser, A. (2005). Relationships between seed yield and yield components and path analysis in some common bean (Phaseolus vulgaris L.) genotypes. Omü Z. F. Dergisi, 20(3), 82-87.

Poehlman, J.M. (1979). Breeding Field Crops. (p. 483). Connecticut: The Avi Publishing Company, Inc..

Shabana, R., Shrief, S.A., Ibrahim, A.F., \& Geisler, G. (1990). Correlation and Path Coefficient Analysis for Some New Released (00) Spring Rapeseed Cultivars Grown under Different Competitive Systems. Journal of Agronomy and Crop Science, 165(2-3), 138-143. doi:10.1111/j.1439-037X.1990. tb00844.x

Şehirali, S. (1971). Türkiyede Yetistirilen Bodur Fasulye Çesitlerinin Tarla Ziraatı, Yönünden Önemli Baslıca Morfolojik ve Biyolojik Vasıfları Üzerinde Arastırmalar. In A.Ü. Ziraat Fakül- 
tesi Yayınları: 474 Bilimsel Araştırma ve Incelemele. (p. 275). Ankara.

Torun, M., \& Köycü, C. (1999). Mısır bitkisinde tane verimi ile bazı verim unsurları arasındaki ilişkilerin saptanması. Tr. J. of Agriculture and Forestry, 23, 1021-1027.

Westermann, D.T., \& Crothers, S.E. (1977). Plant population effects on the seed yield components of beans. Crop Sci., 17, 493-496.
Yılmaz, , \& ve Çiftçi, N.V. (1994). Van Ekolojik Kosullarında Verimli Kuru Fasulye (Phaseolus vulgaris L.) Çeşitlerinin Belirlenmesi ve Verim Komponentlerinin Tane verimine Etkisi Üzerine Bir Araştırma.

Yorgancılar, Ö., Kenar, D., \& Şehirali, S. (2003). Farklı azot dozu uygulamasının bodur fasulye çeşitlerinin verim ve verim öğeleri üzerine etkisi. In Türkiye 5. Tarla Bitkileri Kongresi (1317 Ekim 2003), Diyarbakır. (pp. 555-559).

\title{
Korelaciona i path analiza prinosa i komponenti prinosa u genotipovima pasulja (Phaseolus vulgaris $\mathrm{L}$.)
}

\author{
Mustafa Önder • Ali Kahraman • Ercan Ceyhan
}

Sažetak: Određivanje oplemenjivačkih kriterijuma je veoma važno za oplemenjivače. Ovo istraživanje je sprovedeno da bi se utvrdio prinos i njegove komponente koje imaju uticaj na prinos semena, kao i da bi se izučili odnosi između komponenti prinosa i drugih karakteristika. Ukupno 42 genotipa pasulja koji su gajeni širom Turske su korišćeni kao materijal. Direktni i indirektni efekti komponenti prinosa na prinos semena su analizirani koristeći path analizu. $\mathrm{Na}$ prinos semena (kg ha-1) najveći pozitivni uticaj su ispoljili biološki prinos $(84,56 \%)$ i žetveni indeks $(65,47 \%)$, a negativni broj glavnih stabljika po biljci $(28,45 \%)$ i dana do cvetanja $(13,27 \%)$. Korelaciona analiza je pokazala da su na prinos semena (kg ha-1) pozitivni uticaj ispoljili biološki prinos $\left(0,8224^{* *}\right)$, žetveni indeks $\left(0,2913^{* *}\right)$, a negativni dani do cvetanja $\left(-0,3256^{* *}\right)$, visina prve mahune $\left(-0,2473^{* *}\right)$, visina biljke $\left(-0,2406^{* *}\right)$ i broj mahuna po biljci $\left(-0,2272^{*}\right)$. Prema path analizi, biološki prinos, žetveni indeks, broj glavnih stabljika po biljci i dani do cvetanja su značajni zbog direkton efekta na povećanje prinosa semena u selekcionim ispitivanjima.

Ključne reči: komponente prinosa, pasulj, path analiza, prinos semena 